УДК 343

DOI https://doi.org/10.17308/vsu.proc.law.2020.3/2992

\title{
МЕЖДИСЦИПЛИНАРНЫЙ ПОДХОД К ФОРМИРОВАНИЮ СИСТЕМЫ АНТИКОРРУПЦИОННОГО КОМПЛАЕНСА В РОССИЙСКОЙ ФЕДЕРАЦИИ
}

\author{
Ю. П. Гармаев \\ Бурятский государственный университет илени Доржи Банзарова
}

\author{
Э. А. Иванов, С. А. Маркунцов
}

Национальный исследовательский университет

"Высшая школа эконолики"

Поступила в редакцию 29 мая 2020 г.

Аннотация: впервые обосновывается необходимость междисииплинарного подхода $к$ бборлированию содержательной стороны систель антикоррупиионного колплаенса в Российской Федерации. Данньй подход подразулевает разработку не только организационньх основ. Основное внимание уделено идее использования достижений наук международного права, уголовного права, крилиналистики и оперативно-розыскной деятельности при разработке, внедрении и реализации антикоррупционных политики и процедур в корпоративнол секторе. Авторами предложено собственное определение антикоррупиионного колплаенса, дана его обшая характеристика, расслотрены причины внедрения в корпоративную практику. Проанализированы особенности правового регулирования антикоррупиионного колплаенса в России и за рубежол. Предпринята попьткка институционализации понятийного аппарата, таких взаилосвязанных в контексте фборлируелой кониепиии научных категорий, как коррупиионное преступление, преступление коррупиионной направленности, коррупиионный риск. Основной иелью внедрения в организаииях антикоррупиионного колплаенса является предотвращение совершения коррупиионных деяний (преступлений и иных правонарушений) салили организацияли, сотрудникали и деловыли партнерали. Авторы приходят к выводал о тол, что содержательная сторона антикоррупиионного колплаенса должна строиться с учетол междисииплинарньх классификаций коррупиионных преступлений приленительно к корпоративнолу сектору, отобранных по специальной методологии выборочных данных из уголовно-правовых, криминалистических и оперативно-розыскных характеристик соответствующих противоправных посягательств, а также из методик их расследования. Антикоррупиионньй колплаенс должен быть ориентирован на вьявление и снижение коррупиионных рисков (леждисииплинарного характера), включая необоснованнье риски - риски незаконного привлечения к уголовной ответственности. По мнению авторов, предложенный междисииплинарный подход должен использоваться при разработке и внедрении стандартов и реколендаций в сфере антикоррупционного колплаенса, обеспечивающих защиту российских колпаний от коррупиионных рисков. Данный подход повысит универсальность и практическую значилость антикоррупиионных политики и процедур, а просветительские методы обеспечат их понилание и поддержку в широких слоях населения.

(C) Гармаев Ю. П., Иванов Э. А., Маркунцов С. А., 2020 
Ключевые слова: антикоррупционное просвещение; антикоррупиионная практика, антикоррупиионный колплаенс, защита от незаконного обвинения, комплаенс, корпоративный сектор, коррупиионные преступления, предупреждение коррупиии.

Abstract: the article proposes an interdisciplinary approach to the development of the anti-corruption compliance concept in the Russian Federation. According to the authors, the anti-corruption compliance system should incorporate the main achievements of the sciences of international law, criminal law, criminal procedure law, criminalistics, and investigative activities. This approach can contribute to designing, implementing, and maintaining effective anti-corruption compliance programmes in the corporate sector. The authors propose an own definition and a general overview of the anti-corruption compliance, and analyse main reasons for implementation of anti-corruption compliance in companies. Special attention is paid to distinctive features of legal regulation of the anti-corruption compliance in Russia and in foreign countries. The article contributes to the integration of main scientific definitions and concepts from criminal law and criminalistics, such as corruption crime, corruption offences and corruption risks into the concept of anti-corruption compliance system. The main aim of implementation of the anti-corruption compliance in companies is to prevent committing corruption offences by employees, business partners and other associated persons. The authors come to the conclusions that the use of interdisciplinary classifications and descriptions of corruption offences and best investigative methods and practices can significantly increase an effectiveness of anti-corruption compliance programmes. According to the authors, the proposed interdisciplinary approach can be used for development and implementation of anti-corruption compliance standards and guidelines aimed at protection of Russian companies from corruption risks.

Key words: anti-corruption, anti-corruption compliance, anti-corruption education, compliance, corporate sector, corruption crime, corruption offences, corruption prevention.

Коррупция - это сложное, многогранное, глобальное, социально негативное явление, носящее комплексный, системный характер.

Современная коррупция развивается под влиянием различных факторов общественной жизни, таких как формирование глобальных рынков товаров и услуг, отсутствие границ в отдельных регионах мира, внедрение новых технологий управления и ведения бизнеса, появление криптовалют и новых платежных систем.

Негативное влияние коррупции на общество и государство сложно переоценить. Коррупция убивает доверие граждан к органам государственной власти, стимулирует ведение бизнеса в теневом секторе и уклонение от уплаты налогов, существенно снижает профессионализм и эффрективность работы государственного аппарата.

Коррупция тесно связана с транснациональной организованной преступностью и играет важную вспомогательную роль для таких видов организованной преступной деятельности, как незаконный оборот наркотических средств и психотропных веществ, незаконная торговля, торговля людьми, контрабанда нелегальных мигрантов, легализация преступных доходов. Коррупционные связи могут использоваться для 
обеспечения перемещения денежных средств в рамках финансирования терроризма.

Наряду с коррупцией в публичной сфере, получила распространение и коррупция в сфере бизнеса, основным проявлением которой является коммерческий подкуп. Коррупция в сфере бизнеса оказывает негативное влияние на выбор подрядчиков и поставщиков при проведении тендерных процедур, эффективность размещаемой рекламы, приводит к утечке информации, составляющей коммерческую тайну. Решения, принимаемые менеджерами компаний в результате коммерческого подкупа, наносят существенный экономический, а в ряде случаев и репутационный, ущерб компаниям.

В России исследованиями проблемы коррупции занимались В. В. Астанин, О. Я. Баев, Ю. В. Голик, И. А. Дамм, А. И. Долгова, А. М. Иванов, С. М. Иншаков, Н. А. Лопашенко, В. А. Номоконов, Б. А. Осипов, Е. В. Смахтин, Н. В. Сторчилова, А. Л. Репецкая, А. Н. Халиков, Н. В. Щедрин и многие другие. Авторам удалось проанализировать различные формы коррупции в системе государственной и муниципальной службы, разработать целый ряд мер, направленных на предотвращение коррупции, рекомендации по выявлению, пресечению и расследованию коррупционных преступлений. Среди зарубежных исследований хотелось бы отметить работы М. Джонстона, Р. Клитгарда, М. Леви, Л. Холмса.

На протяжении многих лет меры по противодействию коррупции были направлены на предотвращение, выявление и расследование коррупционных правонарушений и преступлений в государственном и муниципальном секторе. Данные задачи решались прежде всего правоохранительными органами и специальными службами. Традиционными направлениями противодействия коррупции являются установление уголовной и иной юридической ответственности за совершение преступлений и правонарушений коррупционной направленности, установление обязанностей и ограничений для государственных и муниципальных служащих; декларирование доходов и расходов; антикоррупционная экспертиза проектов законодательных и нормативных правовых актов.

Вместе с тем в последние десятилетия в мировой практике активно развивается относительно новое направление в системе противодействия коррупции - внедрение в организациях системы антикоррупционного комплаенса.

Настоящая статья является результатом совместного исследования авторов, направленного на формирование междисциплинарной научной концепции антикоррупционного комплаенса в Российской Федерации.

При проведении исследования использовались диалектический, dopмально-логический, сравнительно-правовой методы и методы статистического анализа и моделирования. 


\section{Постановка проблемы: общая характеристика и причины внедрения антикоррупционного комплаенса}

Антикоррупционный комплаенс является одним из видов комплаенса, наряду с антимонопольным, налоговым, экологическим и рядом других.

На наш взгляд, можно дать следующее базовое определение антикоррупционного комплаенса. Антикоррупционный комплаенс представляет собой процесс управления, который позволяет определять применимые правовые нормы, выявлять и оценивать коррупционные риски, создавать локальные нормы организации, с учетом этических принципов, а затем принимать меры, направленные на соблюдение организацией и взаимодействующими с ней лицами правовых норм, локальных норм организации и профилактику коррупционных рисков. Основными внутренними документами организации, регулирующими разработку и внедрение системы антикоррупционного комплаенса, являются кодекс деловой этики и антикоррупционная комплаенс-программа.

В большинстве стран антикоррупционный комплаенс не является обязательным. Внедрение в компаниях антикоррупционного комплаенса обусловлено различными причинами, которые можно разделить на несколько групп.

В первую группу входят субъективные причины, личная позиция руководителей и владельцев компаний в отношении неприемлемости коррупции. Такая позиция может быть обусловлена как этическими принципами и ценностями руководителей и владельцев, так и сугубо прагматичным желанием снизить риски коррупции на уровне менеджеров среднего звена и сотрудников, предотвратить возможный экономический ущерб.

Ко второй группе можно отнести юридические причины. Так, Закон Великобритании «О взяточничестве» предусматривает, что наличие эфрфективной комплаенс-программы может позволить компании избежать уголовной ответственности ${ }^{1}$. В ряде стран законодательство и решения высших судебных органов допускают возможность существенного снижения штрафов при наличии эффрективной антикоррупционной комплаенс-программы (Бразилия, Германия, США).

В России принятие организациями мер по предупреждению коррупции предусмотрено ст. 13.3. Федерального закона от 25 декабря 2008 г. № 273-ФЗ «О противодействии коррупции», вступившей в силу с 1 января 2013 г. $^{2}$

${ }^{1}$ UK Bribery Act of 2010. URL: http://www.legislation.gov.uk/ukpga/2010/23/contents

${ }^{2} \mathrm{O}$ внесении изменений в отдельные законодательные акты Российской Федерации в связи с принятием Федерального закона "О контроле за соответствием расходов лиц, замещающих государственные должности, и иных лиц их доходам» : фредер. закон от 3 декабря 2012 г. № 231-ФЗ // Собр. законодательства Рос. Федерации. 2012. № 50 (ч. 4). Ст. 6954. 
Третья группа включает рыночные причины. Стремясь снизить риски вовлечения в совершение преступлений коррупционной направленности, компании, особенно крупные, занимающие лидирующие позиции на рынке, требуют от своих партнеров внедрить антикоррупционный комплаенс. Соответствующие положения могут включаться в антикоррупционную оговорку к договорам. Оговорка является неотъемлемой частью договора, ее нарушение может являться основанием для расторжения договора в одностороннем порядке. Наличие антикоррупционного комплаенса может являться обязательным условием участия в коллективных антикоррупционных инициативах объединений предпринимателей и совместных антикоррупционных инициативах государства и бизнеса.

\section{Отличительные особенности правового регулирования антикоррупционного комплаенса}

Исследования, проведенные одним из авторов настоящей статьи, показали, что антикоррупционный комплаенс по своей природе близок к внутреннему контролю в целях противодействию легализации (отмыванию) доходов, полученных преступным путем, и финансированию терроризма ${ }^{3}$. При этом подходы законодателей к регулированию данных видов комплаенса существенно отличаются.

Законодательство государств о противодействии легализации (отмыванию) доходов, полученных преступным путем, и финансированию терроризма, в том числе и законодательство Российской Федерации, разработано на основе Международных стандартов по противодействию отмыванию денег, финансированию терроризма и финансированию распространения оружия массового уничтожения (Рекомендаций ФАТФ) ${ }^{4}$. Обязанности организаций в сфере противодействия легализации (отмыванию) доходов, полученных преступным путем, и финансированию терроризма и формальные требования к структуре и содержанию антиотмывочной комплаенс-программы детально определены в законодательных и подзаконных актах.

В сфере антикоррупционного комплаенса существует более тридцати международных стандартов и руководств, опубликованных международными межправительственными и неправительственными организациями, международными предпринимательскими объединениями и ведущими международными консультантами ${ }^{5}$. Ни один из этих стандартов и

${ }^{3}$ CM.: Ivanov E. AML/CFT and anti-corruption compliance regulation: two parallel roads? // IACA Research Paper Series № 2/2018. URL: http://iaca.int/images/ Research/Research_paper_02_Eduard_Ivanov_final.pdf

${ }^{4}$ International standards on combating money laundering, the financing of terrorism and proliferation (the FATF Recommendations). [pdf] FATF. URL: http:// www.fatfgafi.org/media/fatf/documents/recommendations/pdfs/FATF_Recommendations.pdf

${ }^{5}$ Cm.: Ivanov E. Overview of Anti-Corruption Compliance Standards and Guidelines. Practical Tool. URL: https://www.iaca.int/images/Research/Overview_of_Compliance_Standards_and_Guidelines.pdf 
руководств не получил всеобего признания, сопоставимого по уровню с признанием Рекомендаций ФАТФ. Какая-либо иерархия стандартов и руководств также отсутствует. Существуют руководства, посвященные антикоррупционной комплаенс-программе в целом или ее отдельным разделам. Соответственно, компании могут использовать при внедрении антикоррупционного комплаенса любые стандарты и руководства. На национальном уровне рекомендации для организаций по разработке и внедрению антикоррупционных комплаенс-программ приняты только в восьми государствах ${ }^{6}$. Некоторые государства рекомендуют компаниям использовать стандарт ISO 37001.

В связи с отсутствием общепризнанного стандарта или руководства на международном уровне, а также национальных стандартов и руководств в большинстве стран многие компании используют при разработке антикоррупционных комплаенс-программ иностранные руководства и рекомендации. Особое внимание уделяется рекомендациям регуляторов Великобритании и США, поскольку антикоррупционное законодательство этих стран имеет экстратерриториальное действие. Компании, относящиеся к малому и среднему бизнесу, учитывают также антикоррупционные комплаенс-программы крупных компаний, являющихся их партнерами.

Необходимо отметить, что в России регуляторы стремятся оказать компаниям необходимую методическую помощь во внедрении антикоррупционного комплаенса. Министерством труда и социальной защиты Российской Федерации 8 ноября 2013 г. были опубликованы Методические рекомендации по разработке и принятию организациями мер по предупреждению и противодействию коррупции, получившие в 2019 г. дальнейшее развитие в рекомендациях и письмах по вопросам оценки коррупционных рисков и закреплению обязанностей работников, связанных с предупреждением коррупции.

Заметную роль в продвижении антикоррупционного комплаенса играет Центральный банк Российской Федерации. Концепция организации системы внутреннего контроля для некредитных фринансовых организаций, опубликованная Банком России 31 октября 2017 г., предусматривает в числе основных задач органов внутреннего контроля разработку внутренних документов, направленных на противодействие коммерческому подкупу и коррупциит . Идеи концепции получили развитие в Указании Банка России от 15 марта 2018 г. № 4739-У «О требованиях к организации и осуществлению клиринговой организацией внутреннего контроля и внутреннего аудита» ${ }^{8}$ и Указании Банка России от 7 мая

${ }^{6}$ Бразилия, Великобритания, Италия, Перу, США, Россия, Украина, Франция.

${ }^{7}$ Концепция организации системы внутреннего контроля для некредитных финнансовых организаций. URL: www.cbr.ru/content/document/file/27671/inf_note_ oct_3117.pdf

${ }^{8}$ Вестник Банка России. 2018. № 46. 
2018 г. № 4792-У «О требованиях к порядку осуществления организатором торговли внутреннего контроля и внутреннего аудита ${ }^{9}$.

Несмотря на принятие ст. 13.3 Федерального закона «О противодействии коррупции» внедрение антикоррупционного комплаенса в России протекает медленно. Одной из основных причин такой ситуации является понимание антикоррупционного комплаенса во многих компаниях как еще одного набора бюрократических документов и процедур, требующего регулярных расходов и не дающего реального эффекта.

Представляется, что антикоррупционный комплаенс должен стать реальным механизмом защиты интересов компаний от коррупционных правонарушений и преступлений и способствовать проведению государственной антикоррупционной политики. Для этого антикоррупционный комплаенс должен стать не просто красивым описанием бизнес-процессов и соответствующих превентивных мер, но вобрать в себя огромный опыт предупреждения и выявления преступлений и правонарушений коррупционной направленности, накопленный в криминологии, криминалистике, науке уголовного права, уголовного процесса и оперативно-розыскной деятельности. По мнению авторов, назревает необходимость научной разработки междисциплинарной концепции антикоррупционного комплаенса в Российской Федерации.

\section{Предпосылки использования междисциплинарного подхода к формированию системы антикоррупционного комплаенса}

Следует констатировать, что корпоративные антикоррупционные практики в современной России весьма юны и редки. При этом даже отдельные новации по их развитию в формате комплаенс-системы организационного, методического, правового, образовательного обеспечения проявятся в эффректе, который сократит необходимость прибегать к правоохранительным и судебным мерам защиты публичных коммерческих образований от последствий коррупции ${ }^{10}$.

Соглашаясь с данной позицией, дополним ее следующим тезисом. Антикоррупционный комплаенс подлежит развитию не в порядке отдельных новаций, а на основе внедрения в методологию научных ис-

266 следований и корпоративную практику междисциплинарного подхода с акцентом на содержательную сторону антикоррупционного комплаенса. Данный тезис подлежит подробному обоснованию.

Считается, что комплаенс - это некая корпоративная идеология (часть идеологии), которая направлена на продвижение требований по соответствию внутренним нормативам предприятия и общепринятым социальным ценностям. Реализация такой идеологии предполагает формирование условий для того, чтобы представители компании при совер-

${ }^{9}$ Вестник Банка России. 2018. № 72.

${ }^{10}$ См.: Астанин В. В. Корпоративный антикоррупционный комплаенс : проблемы и ресурсы практического обеспечения // Рос. юстиция. 2017. № 10. С. 5-8. 
шении определенных действий руководствовались стандартами, которые предполагает комплаенс-контроль ${ }^{11}$.

Анализ научных исследований по проблемам антикоррупционного комплаенса, проводившихся российскими и зарубежными учеными, показывает, что почти все они посвящены в первую очередь вопросам организации соответствующих управленческих процессов. Содержательной стороне этой деятельности не уделяется должного внимания. Труды зарубежных ученых анализируют в основном вопросы комплаенс-менеджмента ${ }^{12}$ и не уделяют должного внимания взаимосвязям комплаенса с науками уголовного права, уголовного процесса, криминалистики и оперативно-розыскной деятельности.

\section{Уголовно-правовые аспекты антикоррупционного комплаенса в контексте существующих подходов к противодействию коррупции}

К выводам о недостаточной разработанности содержательной стороны антикоррупционного комплаенса с позиции науки уголовного права приходят П. С. Яни и Н. В. Прохоров. По мнению авторов, практически все публикации на тему антикоррупционного комплаенса посвящены вопросам организации подобной работы. Содержательным элементам деятельности внимание уделяется в значительно меньшей степени. Что же касается ее уголовно-правовой составляющей, то такого рода исследования носят единичный и нередко поверхностный характер ${ }^{13}$. Авторы под содержательным элементом антикоррупционного комплаенса в уголовно-правовой сфере предлагают понимать установление применимых уголовно-правовых норм, предусматривающих как ответственность за коррупционные преступления (исполнителя и иных соучастников, за оконченное и неоконченное преступление и т. д.), так и освобождение от нее, а также обстоятельства, исключающие преступность деяний, содержащих на первый взгляд все признаки составов коррупционных преступлений ${ }^{14}$.

Авторы настоящей статьи в целом поддерживают идею о необходимости комплексного восприятия и оценки уголовно-правовых рисков в сфрере антикоррупционного комплаенса на протяжении всего цикла их существования. Вместе с тем необходимо отметить, что указанное определение не представляется в полной мере удачным ввиду того, что при опре-

${ }^{11}$ См.: Храликин А. А. Антикоррупционный комплаенс-контроль при проведении закупок // Государственные и муниципальные закупки - 2017 : сб. докладов XII Всероссийской практ. конф.-семинара. М., 2017. С. 95-100.

${ }^{12}$ Cм., например: Neiger B. Successful Compliance. Vienna: Austrian Standards plus GmbH. 2015 ; Rho H.-K. The Compliance Role: A proposal for Improved Understanding. URL: http://www.iaca.int/wwwtest/media/attachments/2018/06/18/research_paper_03_han_kyun_rho_final_.pdf

${ }^{13}$ См.: Яни П. С., Прохоров Н. В. Антикоррупционный комплаенс в уголовно-правовой сфере : содержательный элемент // Рос. юстиция. 2018. № 9. С. 54-57.

${ }^{14}$ См.: Там же. С. 55. 


\section{Вестник ВГУ. Серия: Право}

делении содержательного элемента антикоррупционного комплаенса в уголовно-правовой сфрере ученые оперируют понятиями, выработанными в рамках существующей системы противодействия коррупции, которая практически полностью ориентирована на сфреры государственной и муниципальной службы. В частности, не вполне удачным в этом контексте представляется упоминание про «ответственность за коррупционные преступления». Представляется, что таким образом с одинаковым успехом вместо содержательного элемента антикоррупционного комплаенса в уголовно-правовой сфрере можно было бы определить содержательный элемент противодействия коррупции средствами уголовного права. Впрочем, П. С. Яни и Н. В. Прохоров не ограничиваются лишь определением обозначенного содержательного элемента, они наполняют его посредством приведения, как обозначают сами ученые, некоторых из многочисленных порождающих уголовно-правовые риски заблуждений относительно содержания уголовно-правового запрета. Далее, в частности, рассматриваются риски и возникающие в их связи заблуждения в отношении взятки-благодарности, взятки за использование авторитета должности, взятки за общее покровительство, размера взятки, окончания получения взятки и покушения на ее получение, корыстного мотива должностного лица, мелкой взятки и продолжаемого взяточничества и т. д. ${ }^{15}$ Все приведенные примеры связаны с получением взятки, дачей взятки, мелким взяточничеством, посредничеством во взяточничестве. Безусловно, понимая, что указанные преступления относятся к преступлениям коррупционной направленности (коррупционным преступлениям), отметим, что взятка может даваться от имени либо в интересах юридического лица лицами, выполняющими управленческие фрункции в коммерческой или иной организации и пр. Вместе с тем возникает вопрос: почему содержательный элемент антикоррупиионного колплаенса в уголовно-правовой сфрере раскрывается на примере одних из базовых преступлений против порядка управления (против государственной власти), пусть даже и относящихся к преступлениям коррупционной направленности.

Как было отмечено ранее, в настоящее время вся система противодействия коррупции в России почти монопольно ориентирована на ее превенцию в области государственной и муниципальной службы. Парадокс состоит в том, что на это был изначально ориентирован базовый Федеральный закон «О противодействии коррупции» с соответствующим понятийным аппаратом.

Как известно, после ратификации Россией двух важнейших антикоррупционных международных договоров - Конвенции ООН против коррупции ${ }^{16}$ и Конвенции об уголовной ответственности за корруп-

${ }^{15}$ Подробнее см.: Яни П. С., Прохоров Н. В. Указ. соч. С. 55-57.

16 Конвенция Организации Объединенных Наций против коррупции от 31 октября 2003 г. была подписана от имени Российской Федерации в г. Мерида (Мексика) 9 декабря 2003 г. О ратификации Конвенции см.: О ратификации Конвенции Организации Объединенных Наций против коррупции : федер. закон от 
цию ${ }^{17}$, содержащих дефинитивные нормы, положения конвенций стали обязательными для российской системы права. Необходимо отметить, что собственно определение коррупции в данных конвенциях отсутствует. Впрочем, из содержания положений конвенций следует, что понятие коррупции трактуется в них шире по сравнению с разработанными ранее определениями в иных документах. Несмотря на это, понятие коррупции, закрепленное в рамках вышеуказанного федерального закона, не отражало в полном объеме тенденций к пониманию соответствующего социально-негативного явления, закрепленных в рамках указанных конвенций.

Базовые понятия и определения, данные на уровне фредерального закона, представляются не вполне удачными, в частности определение понятия коррупция. В соответствии с п. 1 ст. 1 Федерального закона «О противодействии коррупции»: «коррупция: а) злоупотребление служебным положением, дача взятки, получение взятки, злоупотребление полномочиями, коммерческий подкуп либо иное незаконное использование фризическим лицом своего должностного положения вопреки законным интересам общества и государства в целях получения выгоды в виде денег, ценностей, иного имущества или услуг имущественного характера, иных имущественных прав для себя или для третьих лиц либо незаконное предоставление такой выгоды указанному лицу другими фризическими лицами; б) совершение деяний, указанных в подпункте «а» настоящего пункта, от имени или в интересах юридического лица» ${ }^{18}$. Первая часть определения представляет собой собственно перечисление преступлений коррупционной направленности (коррупционных преступлений), предусмотренных ст. 290, 291, 201, 204 УК РФ (дача взятки, получение взятки, злоупотребление полномочиями, коммерческий подкуп). В этой части следует обратить внимание на отдельные терминологические коллизии с текстом УК РФ. Так, в рамках определения указывается на злоупотребление служебным положением и злоупотребление полномочиями. В УК РФ имеется ст. 201 «Злоупотребление полномочиями», в рамках которой уголовная ответственность устанавливается за злоупотребление как раз служебными полномочиями. Тогда в УК РФ существует еще ст. 285 «Злоупотребление должностными полномочиями». Выходит, что законодатель, употребив при определении коррупции понятия «злоупотребление служебным положением» и «злоупотребление полномочиями», либо

8 марта 2006 г. № 40-ФЗ // Собр. законодательства Рос. Федерации от 20 марта 2006 г. № 12 . Ст. 1231.

17 Конвенция об уголовной ответственности за коррупцию ETS № 173 была подписана от имени Российской Федерации 27 января 1999 г. в г. Страсбурге. О ратификации Конвенции см.: О ратификации Конвенции об уголовной ответственности за коррупцию : федер. закон от 25 июля 2006 г. № 125-ФЗ // Собр. законодательства Рос. Федерации. 2006. № 31 (ч. 1). Ст. 3424.

${ }^{18} \mathrm{O}$ противодействии коррупции : федер. закон от 25 декабря 2008 г. № 273ФЗ (в ред. от 24.04.2020) // Собр. законодательства Рос. Федераии. 2008. № 52 (ч. 1). Ст. 6228. 


\section{Вестник ВГУ. Серия: Право}

подразумевал под последним понятием злоупотребление должностными полномочиями, либо, в сущности, допустил тавтологию, исходя из понимания злоупотребления полномочиями в смысле ст. 201 УК РФ. Также обращает на себя внимание то, что перечень указанных преступлений коррупционной направленности (коррупционных преступлений) не является исчерпывающим, а перечисляются только, на первый взгляд, базовые преступления. Весьма интересным представляется тот фракт, что два из пяти преступлений, через которые дается определение понятия «коррупция», речь в данном случае идет о злоупотреблении полномочиями и злоупотреблении служебным положением, согласно указанию Генпрокуратуры России № 35/11, МВД России № 1 от 24 января 2020 г. ${ }^{19}$, не относятся даже к числу основных преступлений коррупционной направленности. В связи с этим возникают и другие вопросы. В частности, в контексте новелл УК РФ возникают вопросы по поводу отнесения к коррупции мелкого коммерческого подкупа (ст. 204.2 УК РФ), мелкого взяточничества (ст. 291.2 УК РФ). Почему же законодатель определяет коррупцию так сказать «по верхней планке»? Далее в определении коррупции указано на «иное незаконное использование фризическим лицом своего должностного положения». Возникает вопрос: почему здесь речь идет только о должностном положении ${ }^{20}$ (в примечании к ст. 285 УК РФ есть понятие должностного лица) при том, что в этом же определении указано на «злоупотребление служебным положением». И, наконец, исходя из данного определения коррупции можно ли отнести к ней, например, посредничество во взяточничестве (ст. 291.1 УК РФ) - «то есть непосредственная передача взятки по поручению взяткодателя или взяткополучателя либо иное способствование взяткодателю и (или) взяткополучателю в достижении либо реализации соглашения между ними о ствование этим лицам в достижении или реализации соглашения между ними о передаче и получении предмета коммерческого подкупа, в значительном размере»? Следует согласиться с мнением И. С. Алихаджиевой

${ }^{19} \mathrm{O}$ введении в действие перечней статей Уголовного кодекса Российской Федерации, используемых при формировании статистической отчетности : указание Генпрокуратуры России № 35/11, МВД России № 1 от 24 января 2020 г. Документ официально опубликован не был.

${ }^{20}$ Употребление в дефиниции коррупции термина «должностное положение» подразумевает ограничение коррупционных проявлений четко обозначенной в тексте закона сферой, что противоречит преследуемым настоящим нормативным актом целям противодействия коррупции (см.: Алихаджиева И. С. Комментарий к ст. 1 Федерального закона «О противодействии коррупции» // Комментарий к Федеральному закону от 25 декабря 2008 г. № 273-ФЗ «О противодействии коррупции» (постатейный) / под ред. С. Ю. Наумова, С. Е. Чаннова. М., 2009. С. 19). 
о том, что в комментируемой статье допущен ряд других терминологических неточностей и упущений. Так, будет ли понятен правоприменителю смысл словосочетания, введенного в фрормулировку коррупции, «вопреки законным интересам общества и государства", и что считать такими интересами? Означает ли подобная оговорка, что в ходе предварительного расследования коррупционных преступлений подлежат обязательному установлению сам фракт нарушения законных интересов общества и государства и конкретизация пострадавших интересов? Довольно объемная и неточная с позиции уголовного закона формулировка преступных деяний о коррупции препятствует единообразному толкованию текста закона и его правоприменению ${ }^{21}$. Исходя из обозначенной формулировки, возникает и еще один вопрос, весьма принципиальный в контексте проблематики, поднимаемой в рамках обозначенной статьи. $\mathcal{K}$ каким интересам (интересы общества или государства) следует относить частные, корпоративные интересы, на охрану которых, главным образом, и направлено внедрение системы антикоррупционного комплаенса? К сожалению, необходимо констатировать, что сложившаяся «система координат» в рамках действующего российского антикоррупционного законодательства по большому счету не позволяет развиваться системе антикоррупционного комплаенса как полноценной составной части системы противодействия коррупции. Точечные изменения, внесенные в базовый Федеральный закон «О противодействии коррупции» в этой части в рамках ст. 13.3, по сути, лишь обозначили постановку проблемы антикоррупционного комплаенса. Косвенно этот вывод подтверждает и тот фракт, что 3 из 6 предложений, содержащихся в разделе VII «Систематизация и актуализация нормативно-правовой базы по вопросам противодействия коррупции. Устранение пробелов и противоречий в правовом регулировании в области противодействия коррупции» Национального плана противодействия коррупции на 2018-2020 г. ${ }^{22}$, по сути, посвящены совершенствованию уголовно-правового регулирования. В частности, речь идет о предложениях расширения перечня должностных лиц, предусмотренного примечаниями к ст. 285 УК РФ (подп. «а» п. 37), подготовки обзоров судебной практики по уголовным делам (п. 38), установления дополнительных квалифицирующих признаков мелкого взяточничества (подп. «а» п. 39). При этом не указано никаких мер в сфере актуализации нормативно-правовой базы и устранения пробелов и противоречий в правовом регулировании в сфере антикоррупционного комплаенса.

В сорере уголовно-правового регулирования противодействия коррупции также все не столь однозначно. Весьма интересной представляется ситуация, при которой наряду с понятием «преступления коррупционной направленности», признаки и классификация которых предлагается в

${ }^{21}$ Подробнее см.: Там же. С. 23-24.

22 О Национальном плане противодействия коррупции на 2018-2020 годы : указ Президента РФ от 29 июня 2018 г. № 378 // Собр. законодательства Рос. Федерации. 2018. № 27. Ст. 4038. 
рамках обозначенного выше указания Генпрокуратуры России № 35/11, МВД России № 1 от 24 января 2020 г., используется и понятие «коррупционные преступления». В частности, последний из обозначенных терминов употребляется в Стратегии национальной безопасности Российской Федерации (п. 43, 46) ${ }^{23}$ или в указании Генпрокуратуры России от 14 мая 2019 г. № 341/86²4. В абз. 6 преамбулы постановления Пленума Верховного Суда РФ «О судебной практике по делам о взяточничестве и об иных коррупционных преступлениях» пишется о «рассмотрении уголовных дел о взяточничестве (статьи 290, 291 и 291.1 УК РФ) и об иных связанных с ним преступлениях, в том числе коррупционных (в частности, предусмотренных статьями 159, 160, 204, 292, 304 УК РФ)...». Таким образом, к коррупционным преступлениям относятся составы взяточничества и иные связанные с ним преступления, в том числе коррупционные, перечень последних является неисчерпывающим. Достаточно интересным представляется тот фракт, что во вторую группу преступлений попали как преступления, отнесенные к основным преступлениям коррупционной направленности (ст. 204 УК РФ), отнесенные к числу таковых под «условием» (ст. 159, 160, 292 УК РФ), либо даже к числу «способствующих» (ст. 159 УК РФ), так и вообще не отнесенные к преступлениям коррупционной направленности (ст. 304 УК РФ) в соответствии с приложением № 23 к указанию Генпрокуратуры России № 35/11, МВД России № 1 от 24 января 2020 г.

Все это лишний раз свидетельствует об отсутствии единообразного, непротиворечивого понятийного аппарата в сфере правового регулирования противодействия коррупции и антикоррупщионного комплаенса.

\section{Криминалистическая и оперативно-розыскная содержательная составляющая антикоррупционного комплаенса}

В контексте предлагаемого междисциплинарного подхода констатируем также полное отсутствие исследований, посвященных криминалистической и оперативно-розыскной содержательной составляющей антикоррупционного комплаенса. Остановимся подробнее на этих составляющих.

В традиционной структуре науки криминалистики существует завершающий - четвертый раздел под названием «Криминалистическая методика расследования отдельных видов и групп преступлений». В этом разделе одной из наиболее разработанных является группа методик расследования преступных коррупционных посягательств. Речь идет как о методиках, посвященных отдельным видам криминальной коррупции

${ }^{23}$ О Стратегии национальной безопасности Российской Федерации : указ Президента РФ от 31 декабря 2015 г. № 683 // Собр. законодательства Рос. Федерации. 2016. № 1 (ч. 2). Ст. 212.

${ }^{24} \mathrm{O}$ порядке работы органов прокуратуры Российской Федерации по привлечению к ответственности юридических лиц, от имени или в интересах которых совершаются коррупционные преступления : указание Генпрокуратуры России от 14 мая 2019 г. № 341/86 // Законность. 2019. № 6. 
исходя из уголовно-правовой квалифрикации (расследование взяточничества, коммерческого подкупа и т. п.), так и исходя, например, из сорер деятельности: методика расследования коррупционных преступлений в сфрере закупок, в правоохранительных органах, коммерческих организациях и т. п. Каждая из этих методик обычно состоит из двух частей:

1) криминалистической характеристики соответствующей преступной деятельности - данные о типичных субъектах, способах, следах, обстановке преступлений и других элементах;

2) собственно рекомендаций по их выявлению, расследованию и предупреждению ${ }^{25}$.

Примерно аналогичную структуру имеют и так называемые оперативно-розыскные методики. Они включают оперативно-розыскную характеристику преступлений и собственно методические рекомендации. Если кратко, то в отличие от методик криминалистических, в оперативно-розыскных разработках связующим звеном между элементами является агентурно-оперативный аспект ${ }^{26}$. Значительная часть оперативно-розыскных методик носит секретный характер. Они менее разработаны, чем криминалистические методики, хотя сходны по содержанию, а потому для целей антикоррупционного комплаенса, вероятно, чаще должны использоваться вторые.

Обе части криминалистических методик - характеристика преступлений и собственно методика их расследования - ценнейший и пока совершенно невостребованный источник, кладезь полезной инорормации для содержательной стороны антикоррупционного комплаенса. Однако источник этот вряд ли получится использовать непосредственно. Причина проста. Соответствующие разработки адресованы профрессиональным участникам уголовного процесса со стороны обвинения, прежде всего оперативным сотрудникам и следователям. Этот источник информации, вернее его содержание, подлежит глубокой переработке и адаптации криминалистами-разработчиками, например для целей подготовки комплаенс-офицеров и профилактических занятий для менеджмента и сотрудников организаций корпоративного сектора. Переработанный и адаптированный по специальным методологическим правилам контент может информировать указанные целевые аудитории о следующем:

- как совершаются коррупционные преступления в соответствующем корпоративном секторе: не в плане инструкций по совершению преступлений и уклонению от уголовной ответственности, а в контексте того, какими могут быть попытки вовлечения добросовестных сотрудников в преступную деятельность; каковы ее негативные последствия для этих лиц и всей организации;

${ }^{25}$ Примерно то же самое можно сказать об оперативно-розыскных методиках научной категории менее развитой, но от того не менее полезной.

${ }^{26}$ См., например: Мазунин Я. М., Кудрявицкий А. С. О соотношении понятий криминалистической и оперативно-розыскной методик // Оперативник (сыщик). M., 2010. № 3. C. 51-55. 
- какие типичные заблуждения существуют применительно к коррупционной преступной деятельности, а также применительно к работе правоохранительной системы; чем вредны эти заблуждения и как их преодолеть, развенчать. Например, многие ошибочно считают, что запись переговоров, произведенная до возбуждения уголовного дела и без судебного решения не может иметь доказательственного значения;

- как выявляются, раскрываются и расследуются преступные посягательства в контексте: а) неотвратимости уголовного преследования; б) негативных последствий, которые повлечет оно (уголовное преследование) для компании и конкретного менеджера, сотрудника; в) средств и методов защиты от незаконных и/или некомпетентных действий отдельных сотрудников правоохранительных органов.

Последний пункт нуждается в дополнительных пояснениях. Предотвращение совершения коррупционных преступлений требует исследования уголовно-правовых рисков, в том числе необоснованных. Так, П. С. Яни и Н. В. Прохоров, цитируя А. Э. Жалинского, указывают: «В целом необоснованность риска означает возможность: а) применения уголовно-правовой нормы без законного фрактического основания; б) расширительного толкования нормы; в) неправильной уголовно-правовой оценки деяния; г) незаконного или несправедливого наказания... При этом к уголовно-правовым фракторам риска относятся те, которые дают возможность принятия незаконного и несправедливого решения, но не связаны напрямую с открытым нарушением предписаний уголовного закона ${ }^{27}$. Авторы как специалисты в области уголовного права ограничились предметом лишь этой науки. Задача создания междисциплинарной концепции антикоррупционного комплаенса позволяет шире взглянуть на проблему и рассмотреть криминалистические и оперативно-розыскные фракторы риска. Речь идет, например, о рисках проведения против 일 менеджмента компании незаконных оперативно-розыскных мероприятий, применения провокаций, фральсификации доказательств и результатов оперативно-розыскной деятельности и т. п.

Обобщая изложенное, приходим к выводам о том, что междисциплинарной подход к формированию содержательной стороны системы ан-

274 тикоррупционного комплаенса в Российской Федерации, помимо институционализации понятийного аппарата, должен включать следующие информационные блоки:

- междисциплинарные типологии и классификации коррупционных преступлений и иных правонарушений применительно к корпоративному, государственному и некоммерческому сектору;

- уголовно-правовые, криминалистические и оперативно-розыскные характеристики коррупционных преступлений, иных правонарушений, включая их механизмы («схемы») и следы, их общественно опасные последствия и др.;

${ }^{27}$ Цит. по: Яни П. С., Прохоров Н. В. Указ соч. С. 54-57. 
- описание и правовую оценку типичных коррупционных заблуждений уголовно-правового, криминалистического и оперативно-розыскного характера;

- описание и правовую оценку коррупционных рисков междисциплинарного характера, включая необоснованные риски;

- особенности деятельности правоохранительных органов по выявлению, расследованию и предупреждению коррупционных преступлений, иных мер по противодействию коррупции;

- рекомендации, направленные на обеспечение эффрективного сотрудничества между государственными органами, корпоративным и некоммерческим сектором в целях предупреждения и противодействия коррупции.

Все эти данные должны формулироваться не в традиционном (для ученых-юристов и правоприменителей), а в принципиально ином - просветительском формате, кратком и доступном для корпоративного сектора и широких слоев населения.

Вновь подчеркнем, что содержательная сторона антикоррупционного комплаенса должна включать достаточно распространенные закономерности необоснованного уголовного преследования (а также незаконных оперативно-розыскных мероприятий), следственных и судебных ошибок, неправомерных действий конкурентов в рыночной среде, а также клеветы со стороны недобросовестных лиц и СМИ. Все эти риски актуальны для менеджмента (прежде всего) и сотрудников компаний. И они должны быть эфрфективно минимизированы.

Однако считаем недопустимым прямо или косвенно поддерживать негативный имидж сотрудников правоохранительных органов. Ошибки и нарушения закона случаются в любой профессиональной деятельности. Закономерности незаконного и необоснованного привлечения к уголовной ответственности фризических лиц и компаний имеются и в иных, в том числе в экономически развитых странах мира ${ }^{28}$. Сотрудничество с правоохранительными и иными государственными органами является одним из элементов антикоррупционного комплаенса. Своевременное информирование правоохранительных органов, в том числе подразделений собственной безопасности, может позволить защитить компанию от вымогательства и иных противоправных действий, предотвратить серьезные негативные последствия для компании, ее руководителей и сотрудников.

Без содержательного наполнения и использования широкого междисциплинарного подхода антикоррупционный комплаенс останется комплаенсом на бумаге. Описанные выше междисциплинарные элементы

${ }^{28}$ См., например: Cruz J. M. Olice Misconduct and Political Legitimacy in Central America // Journal of Latin American Studies. 2015. 47(2). P. 251-283 ; Stinson P. M. Sr., Liederbach J., Buerger M., Steven L., \& Brewer Jr. To protect and collect: a nationwide study of profit-motivated police crime. Criminal Justice Studies // A Critical Journal of Crime, Law and Society. 2018. 31 (3). P. 310-331. 
содержательной стороны антикоррупционного комплаенса должны стать обязательной составляющей эффрективных антикоррупционных комплаенс-программ в корпоративном секторе.

Представляется необходимым создание междисциплинарной концепции антикоррупционного комплаенса в Российской Федерации. Построение системы не только организационного и правового, но и научного, в том числе образовательно-просветительского обеспечения антикоррупционного комплаенса, позволит добиться долгосрочного позитивного эффекта. Он будет иметь место вне зависимости от некоторых изменений антикоррупционного и иного законодательства, социально-экономических и иных условий именно в силу применения междисциплинарного подхода.

Бурятский государственный университет илени Доржи Банзарова

Гармаев Ю. П., доктор юридических наук, профбессор кафбедры уголовного проиесса и крилиналистики

E-mail: garmaeff1@mail.ru

Национальный исследовательский университет "Высшая школа эконоликu»

Иванов Э. А., доктор юридических наук, проббессор департалента общих и межотраслевых юридических дисииплин фбакультета права

E-mail:eaivanov@hse.ru

Маркуниов С. А., доктор юридических наук, доцент, профбессор фбакультета права; профбессор кафбедры юриспрудениии Московского городского университета управления правительства Москвы илени Ю. М. Лужкова
Buryat State University named after Dorji Banzarov

Garmaev Yu. P., Doctor of Legal Sciences, Professor of the Criminal Process and Criminalistic

E-mail: garmaeff1@mail.ru

National Research University "Higher School of Economics"

Ivanov E. A., Doctor of Legal Sciences, Professor of the General and Interdisciplinary Legal Studies Department

E-mail: eaivanov@hse.ru

Markuntsov S. A., Doctor of Legal Sciences, Associate Professor, Professor of the Faculty of Law, Professor of the Department of Law of the Moscow City University of Management of the Government of Moskow named after Yu. M. Luzhkov

E-mail:smarkuntsov@hse.ru 